\title{
Assessing Crop Yield Sustainability under the Climatic and Bioclimatic Change in the Area of Palestine
}

\author{
Jehad M. H. Ighbareyeh"1, A. Cano-Ortiz' ${ }^{1}$, E. Cano Carmona ${ }^{1}$, Mohammed M. H. Ighbareyeh ${ }^{2}$, \\ Asma A. A. Suliemieh ${ }^{3}$ \\ ${ }^{1}$ Department of Animal and Plant Biology and Ecology, Faculty of Experimental Sciences, University of Jaen, \\ Jaen, Spain \\ ${ }^{2}$ Faculty of Literature, Quds Open University, Hebron, Palestine \\ ${ }^{3}$ Faculty of Sciences, University of Hebron, Hebron, Palestine \\ Email: jehadighbareyeh@hotmail.com
}

Received 17 February 2015; accepted 8 March 2015; published 12 March 2015

Copyright $@ 2015$ by authors and Scientific Research Publishing Inc.

This work is licensed under the Creative Commons Attribution International License (CC BY).

http://creativecommons.org/licenses/by/4.0/

(c) (i) Open Access

\section{Abstract}

We analyzed plant production such as olive, grape and fig in several Palestinian Occupied Territories, and studied the correlation analyses between productions and climatic, bioclimatic features in the territory. This work examines the following climate factors: average temperature, precipitation, soil water reserve and water deficit; and bioclimatic parameters such as compensated thermicity index, ombrothermic index and continentally index. The data used were from nine meteorological stations of the Palestinian Meteorological Department. The study was based on the correlation analyses between olive, grape and fig production in nine plots: Hebron, Ramallah, Nablus, Jenin, Jericho, Bethlehem, Jerusalem and Tulkarem over fourteen years. The analysis of variance revealed a significant influence of the variables temperature and compensated thermicity index on the production of olive and fig, and a low influence on grape production. When we applied canonical correspondence analysis (CCA), the Nablus, Jenin, Jericho and Gaza plots were most affected by the climate factors as temperature, and bioclimate factors as compensated thermicity index, whereas, the Hebron, Bethlehem, Jerusalem, Tulkarem and Ramallah plots showed the influence of ombrothermic index, continentally index, precipitation, water deficit and soil water reserve.

\section{Keywords}

Production, Bioclimatology, Independents Variables, Biology and Climate 


\section{Introduction}

The climate in Palestine is Mediterranean character with a dry summer season from May to October. The rainy season and agricultural year begin in September-October and the rainfall ends in April-May [1]. The winter rain regime has been extensively studied [2]-[7] and also the long-term changes in annual rainfall patterns [8] [9]. Therefore, Palestine is situated in the subtropical dry lands of south-western Asia at a very sensitive climatic position. Palestine bioclimatic belt belongs to the infra-Mediterranean to meso-Mediterranean thermo-type [10]. The atmosphere of Palestine is clear and its air is pure. Summer temperatures reach $35^{\circ}$ centigrade and in the winter, temperature may drop to zero. The inconsistency of rainfall throughout the months and years requires that most vegetable cultivation is supplemented with irrigation to ensure normal growth.

Olive (Olea europaea L.) is one of the most important fruit trees in Palestine, with cultivars as Souri, Nabali Mohassan, Nabali Baladi, Roumi and others. Olive is a Mediterranean species with a very specific biology, as its root system is extremely disperse and does not penetrate deeply into the soil, making it thus considerably susceptible to climate change [11] [12]. Grape (Vitis vinifera L.) is one of the plants fruit trees affected by climatic and biological factors [13], and grapevines are grown in distinct climatic regimes worldwide that provide ideal situations to produce high quality grapes [14]. Whereas, fig (Ficus carica L.) is one of the plants that can tolerate seasonal drought, and the Middle Eastern and Mediterranean climate is especially suitable for the plant. Also the biology of the plant allows its root system to penetrate deeply into the soil in search of the lower levels of the water table.

The aim is to study the relationship between the climatic and bioclimatic factors on plant production, and the effects of climate change on crops.

\section{Materials and Methods}

\subsection{Study Area}

Palestine is located between longitudes $34^{\circ} 15^{\prime}$ and $35^{\circ} 40^{\prime}$ east and between latitudes $29^{\circ} 30^{\prime}$ and $33^{\circ} 15^{\prime}$ north. The geographic location of Palestine plays a major role in affecting the features of its climate and the climate diversity between the southern and northern parts.

\subsection{Data Analysis}

Data were used from the meteorological stations in Palestine in Table 1, Figure 1 for the years 1993 to 2008 (15 years), and for the same years for production of plants (Table 2). The bioclimatology of the aforementioned stations was studied, and the value of the bioclimatic indices as ombrothermic index (Io), continentally index (Ic), and compensated thermicity index (It/Itc) and the climatic factors were obtained according to Rivas-Martinez [15]-[17] and [18].

We analyzed the relationship between the dependent variables as olive, grape and fig production; the independent variables (climate factors) such as average temperature $(T)$, precipitation $(\mathrm{P})$, soil water reserves (R),

Table 1. Coordinates of meteorological stations in Palestine.

\begin{tabular}{|c|c|c|c|}
\hline \multicolumn{4}{|c|}{ Station latitude (north) longitude (east) elevation m } \\
\hline Jenin & $32^{\circ} 28^{\prime} \mathrm{N}^{\prime \prime}$ & $35^{\circ} 18^{\prime} \mathrm{E}$ & $178 \mathrm{~m}$ \\
\hline Tulkarem & $32^{\circ} 19^{\prime} \mathrm{N}^{\prime \prime}$ & $35^{\circ} 01^{\prime} \mathrm{E}$ & $83 \mathrm{~m}$ \\
\hline Nablus & $32^{\circ} 13^{\prime} \mathrm{N}^{\prime \prime}$ & $35^{\circ} 15^{\prime} \mathrm{E}$ & $570 \mathrm{~m}$ \\
\hline Ramallah & $31^{\circ} 89^{\prime} \mathrm{N}^{\prime \prime}$ & $35^{\circ} 21^{\prime} \mathrm{E}$ & $856 \mathrm{~m}$ \\
\hline Hebron & $31^{\circ} 32^{\prime} \mathrm{N}^{\prime \prime}$ & $35^{\circ} 06^{\prime} \mathrm{E}$ & $1005 \mathrm{~m}$ \\
\hline Jericho & $31^{\circ} 51^{\prime} \mathrm{N} "$ & $35^{\circ} 27^{\prime} \mathrm{E}$ & $-260 \mathrm{~m}$ \\
\hline Jerusalem & $35^{\circ} 13^{\prime} \mathrm{N}^{\prime \prime}$ & $31^{\circ} 52^{\prime} \mathrm{E}$ & $750 \mathrm{~m}$ \\
\hline Bethlehem & $35^{\circ} 20^{\prime} \mathrm{N}^{\prime \prime}$ & $31^{\circ} 71^{\prime} \mathrm{E}$ & $276 \mathrm{~m}$ \\
\hline Gaza & $31^{\circ} 30^{\prime} \mathrm{N}^{\prime \prime}$ & $34^{\circ} 27^{\prime} \mathrm{E}$ & $13 \mathrm{~m}$ \\
\hline
\end{tabular}


Table 2. Represents of independents variables (bioclimate factors as annual ombrothermic index, simple continentally index and compensated thermicity index, and climate factors as a temperature, precipitation, deficit water, and soil water reserve); independents variables are consist of olive, fig, and grape production.

\begin{tabular}{ccccccccccc}
\hline Site & $\mathrm{T}$ & $\mathrm{P}$ & $\mathrm{Df}$ & $\mathrm{R}$ & $\mathrm{Itc}$ & $\mathrm{Ic}$ & Io & Olive production Grape production & Fig production \\
\hline Jenin & 20 & 500 & 761 & 400 & 450 & 17.3 & 1.9 & 207 & 500 & 470 \\
Tulkarem & 22 & 620 & 830 & 442 & 477 & 17.2 & 2.4 & 122 & 700 & 400 \\
Nablus & 17 & 683 & 614 & 474 & 350 & 19.1 & 3.2 & 170 & 413 & 650 \\
Jericho & 24 & 166 & 100 & 50 & 550 & 13.1 & 0.8 & 6.78 & 2.5 & 2.5 \\
Ramallah & 16.5 & 615 & 590 & 462 & 311 & 17.8 & 3.4 & 90 & 621 & 393 \\
Jerusalem & 17.4 & 570 & 580 & 413 & 370 & 17.4 & 2.9 & 92 & 700 & 480 \\
Bethlehem & 17 & 585 & 570 & 420 & 390 & 16.8 & 2.8 & 64 & 641 & 325 \\
Hebron & 16.6 & 596 & 583 & 471 & 297 & 18.1 & 3.4 & 141 & 884 & 612 \\
Gaza & 20 & 400 & 500 & 250 & 455 & 13.2 & 1.8 & 100 & 190 & 550 \\
\hline
\end{tabular}

Yield: kg/dunum.

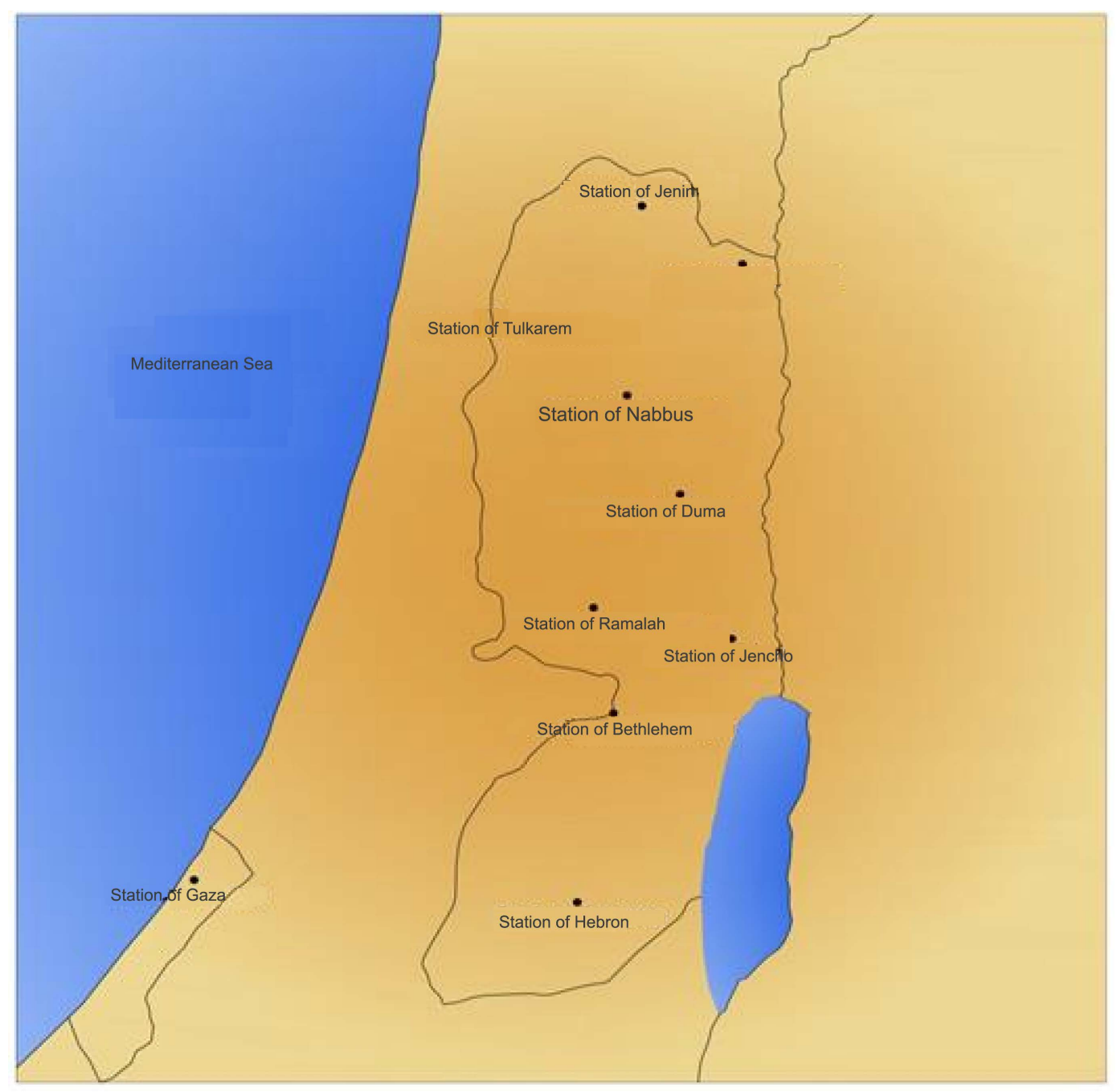

Figure 1. Location of the meteorological Palestinian stations. 
and water deficit (Df), and the bioclimatic variables or factors as Io, Ic, and It/Itc, in order to establish the variables that had the greatest influence on agricultural production in the regions of Palestine.

In this study, the Shapiro-Wilk and Jarque-Bera normality tests were applied [19]-[22], and the p-value was obtained for the seven variables. We applied an ANOVA linear regression analysis to each of the ten independent and dependent variables, the three bioclimatic variables and the four remaining physical variables (climate factors), and each of the dependent variables olive, grape and fig production, in order to obtain the coefficient of regression $\mathrm{R}^{2}$ and the multiple regression line, and canonical correspondence analysis (CCA) were subsequently applied in order to determine the influence of independent variables on production. These statistical analyses were done using the XLSTAT software.

\section{Results and Discussion}

\section{Effect of the Bioclimate and Climate Change on Plant}

We used the bioclimatic classification of earth to Salvador Rivas-Martinez to analyses of the climate factors and bioclimatic parameters (independent variables). After application of the Shapiro-Wilk normality test, the p-value obtained from the variables studied tended to be below 0.05 , a conventionally accepted value.

The analysis of variance (ANOVA), with a 95\% confidence interval, applied to each of the three production variables olive, grape and fig, with the seven independent variable factors T, P, R, Df, Io, Ic and It/Itc, reveals significant differences in the case of olive, grape, and fig production, implying the influence of the seven factors on the production of olive, grape and fig, may be that changes in climatic and bioclimatic factors have an impact on the sustainability of plant production, in the multiple regression analyses, the case of olive and grape production shows a better linear regression correlation with the values of $\mathrm{R}^{2}=0.984,0.960$ respectively, being close to 1 , although the correlation of fig production is small than olive and grape, as $\mathrm{R}^{2}$ is low $(0.892)$. The linear regression correlation analyses between each of the three dependent variables, olive, grape and fig production and the three independent bioclimatic variables have a different level of significance. There are no significant differences in the case of olive and fig production, but there is a statistically significant difference for grape production, as the histogram is positive (Figure 3), because grape production is high in south of Palestine (Table 2). Moreover, the high linear regression correlation between the bioclimatic factors and olive production with values of $\mathrm{R}^{2}=0.984$, and the value of $\mathrm{R}^{2}=0.960$ for grape production, shows the high influence of the independents variables of bioclimate Io, Ic, P, Df, R on the grape production, but low in the case of olive and fig production (Figures 2-4), and that these results are very close, as conducted by Ighbareyeh, J.M.H., et al. [23].

Olive / Standardized coefficients

(95\% confidence interval)

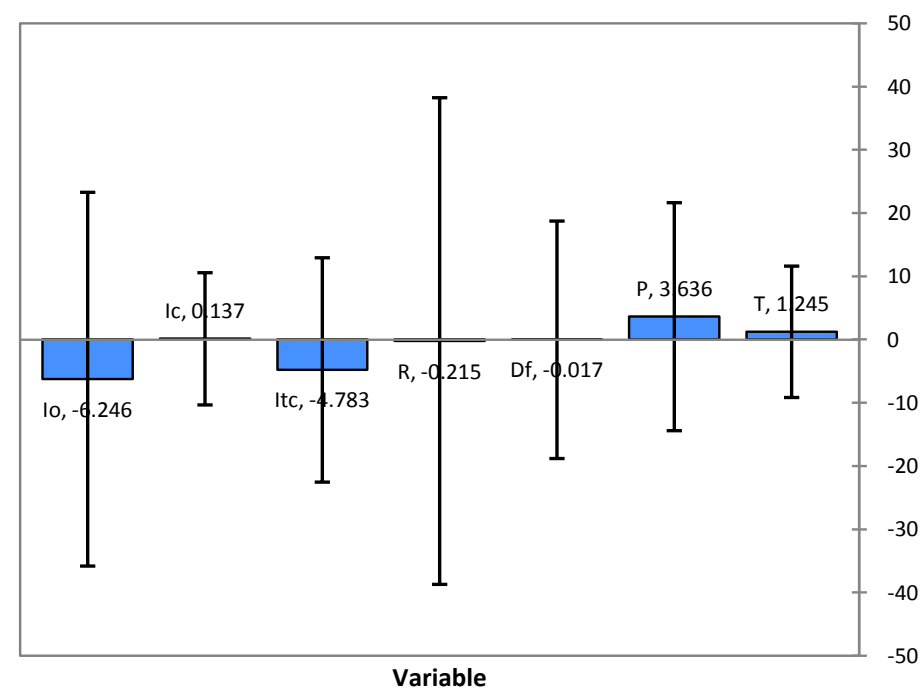

Figure 2. Regression correlation analysis for the olive and independent variables. 


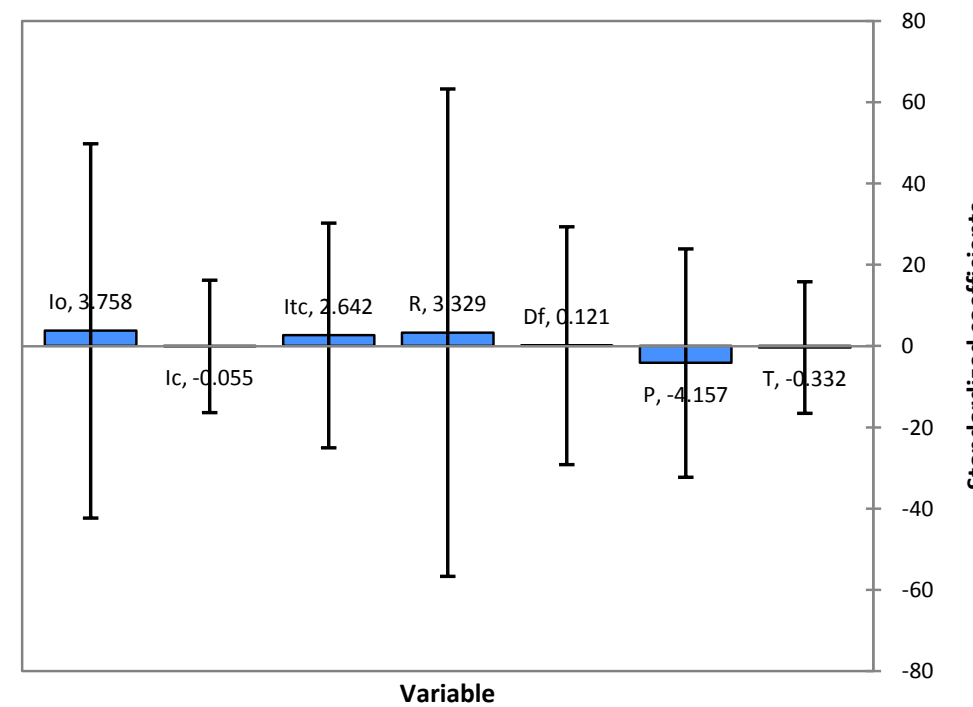

Figure 3. Regression correlation analysis for the grape and independent variables.

Fig / Standardized coefficients

(95\% confidence interval)

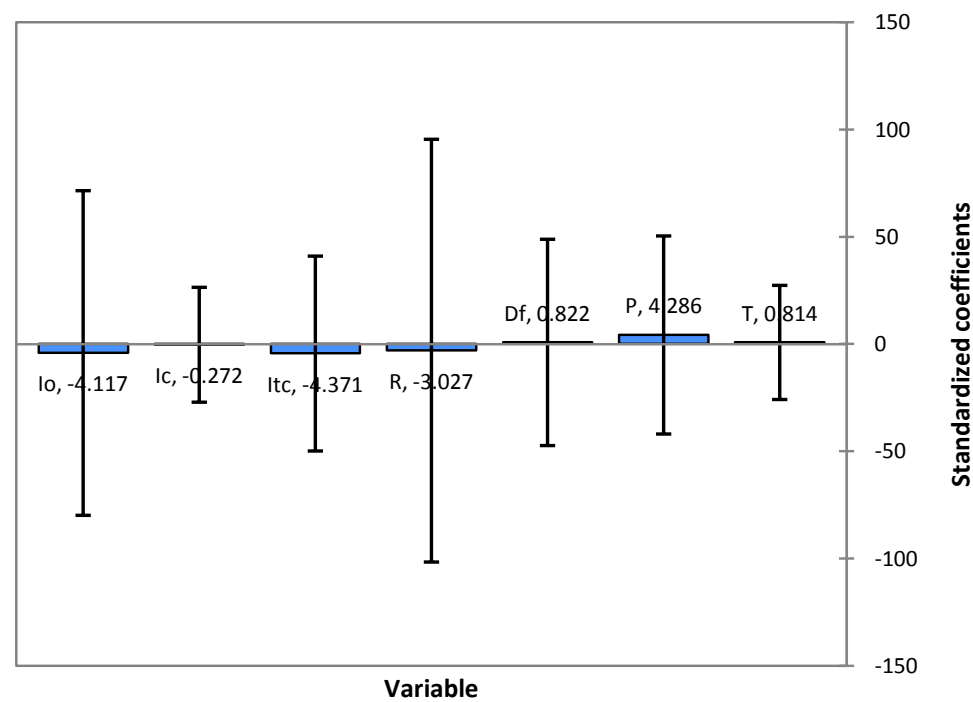

Figure 4. Regression correlation analysis for the fig and independent variables.

On the other side, bioclimatic variables that were not taken into account in the model published by Galán et al. [24] for the Andalusian olive grove. We observed that the olive and fig production were influenced by the climate change as temperature and bioclimate factors as compensated thermicity index because the histogram is positive, while the P, Df, R, Io, and Ic, were negative histogram (Figure 2 and Figure 4).

Nevertheless, when the multiple regression correlation analysis is applied to each of the dependent variables and the seven physical parameters (independent variables), significant differences $(\mathrm{p}<0.05)$ can once again be observed in all cases. These differences are lower in the case of olive production; again in this case the value of $\mathrm{R}^{2}$ obtained in the multiple regression line is 0.984 , thus highlighting the high correlation between olive produc- 
tion and physical parameters.

In view of the linear regression correlation obtained, we applied a canonical correspondence analysis (CCA). This was done by comparing the dependent variables olive, grape and fig production with the total independent variables, the three bioclimatic parameters Io, Ic and It/Itc, and with the four physical parameters, from nine sampling plots. In the first place it was observed that the Nablus, Jenin, Jericho and Gaza type plots are located at the left of axis 1 , and plots are more affected by the $\mathrm{T}$ and It/Itc, while all the Hebron, Bethlehem, Jerusalem, Tulkarem and Ramallah type plots are at the right of axis 2, and reveal the influence of annual ombrothermic index, continentally index, precipitation, water deficit and soil water reserve, with a large proportion of the variance explained by axis 1 (86.41\%), as opposed to axis 2 (13.58\%) (Figure 5), hence, we note that there is the impact of these factors on the production and sustainability of these plants; also, we indicated the climatic andbioclimatic factors affecting biology and plant communities [25].

We observed that there is confirmation of the Nablus, Jenin, Jericho and Gaza type plots were conditioned by the $\mathrm{T}$, It/Itc, underlining the fact that olive and fig production in these plots depends on It/Itc and T, whereas grape production is less influenced by these factors. Therefore, olive and fig production in the Nablus, Jenin, Jericho and Gaza type plots are conditioned by temperature and compensated thermicity index. However, the nature of the relationship between biological system, atmospheric dynamics and temperature is changing [26]-[29].

Hebron, Bethlehem, Jerusalem, Tulkarem and Ramallah were conditioned by continentally index, water deficit and others factors, as in the upper thermo-Mediterranean and lower meso-Mediterranean environments, the optimum for the production of olives is achieved with values of Ic more than 18 and Io = 3.6 - 4.0 [30] [31], and Io $=3-4$, and It/Itc is about 300 for the production of grape [23], grape is a very responsive to their surrounding environment with a seasonal variation in yield of $32.5 \%$ [13]. Climate is one of the key controlling factors in grape production, [32] affecting the suitability of certain grape varieties to a particular region as well as the type

\section{CCA Map / Symmetric}

(axes 1 and 2: $100.00 \%$ )

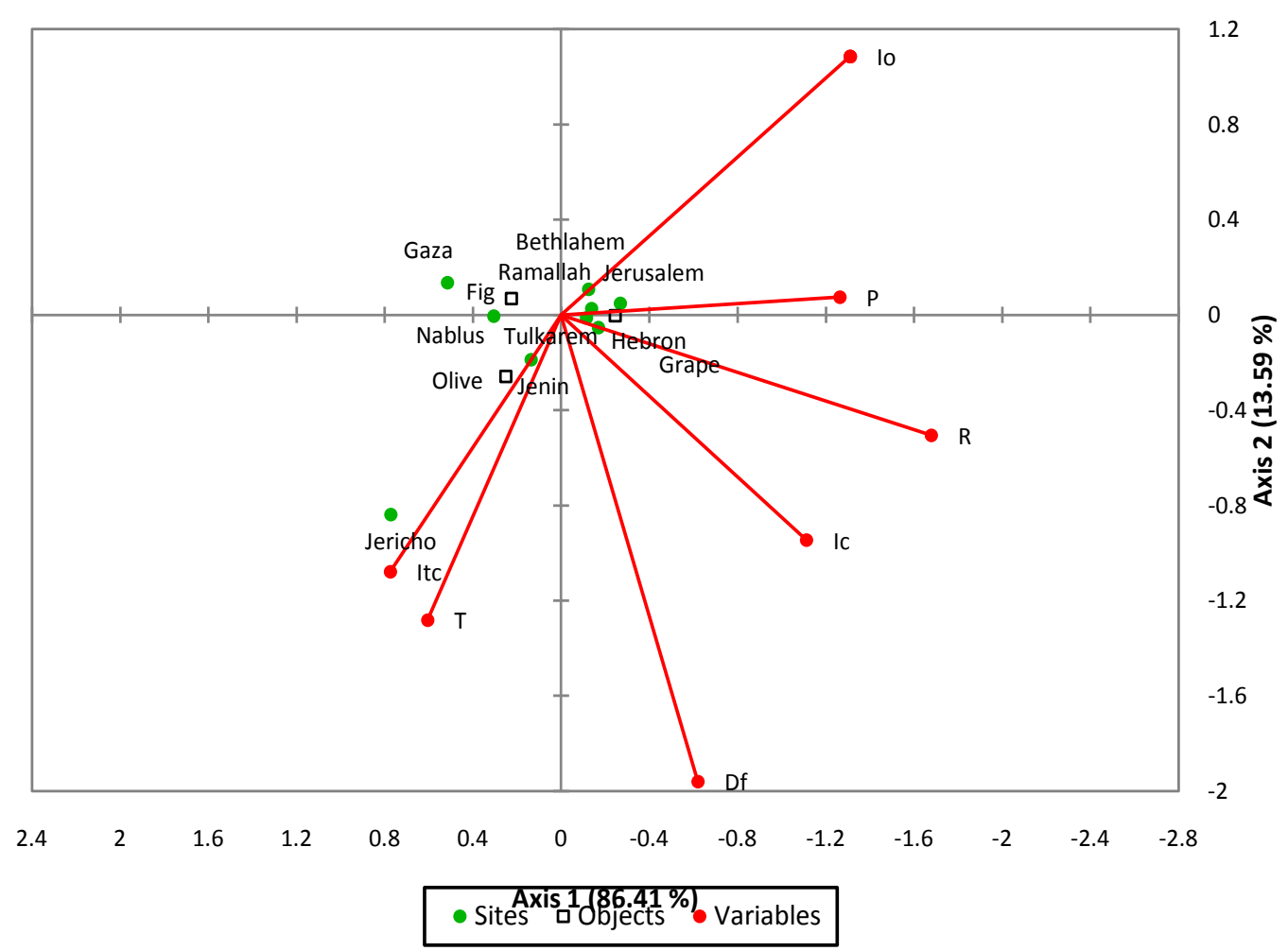

Figure 5. Canonical correspondence analysis (CCA), with independent variables (climate and bioclimate factors) and variables dependents. 
and quality of the wine produced. However, the interaction between climate-soil-variety will in some cases come under threat from the effects of climate change. Identification of genes underlying phonological variation in grape may help to maintain consistent yield of particular varieties in future climatic conditions [33]. Mild to cool and wet winters followed by warm springs, then warm to hot summers with little precipitation provide adequate growth potential and increase the likelihood of higher wine quality [34]-[36] and [14].

In the (CCA), with a variance of $86.41 \%$ (Figure 5) between production and environmental factors (T, It/Itc) explained by axis 1, whereas in plots type Hebron, Tulkarem, Bethlehem, Jerusalem and Ramallah, production depends on precipitation, also, the annual precipitation rates are deemed likely to fall in Palestine decreasing with an increased risk of summer drought [25] [37] [38], and the effect of reduced precipitation could result in reducing annual groundwater recharge in the West Bank by $30 \%$ of existing value [39]; and soil water reserves and water deficit, maybe, this is probably also due to the lack of rainfall in general for these areas and the type of soil, therefore, storm water runoff are affected by soil types and local variations [40] [41]. And so we need to study strategic climate change adaptation planning and monitoring of groundwater quality and quantity, and the soil type and quality.

\section{Conclusions}

Bothclimatic and bioclimatic factors play a very important role in plant biology, in the production, sustainability of crop yield and lead to an increase in economy in Palestine. The annual precipitation rates are deemed likely to fall in Palestine decreasing with an increased risk of summer drought.

The multiple regression analysis reveals that bioclimatic variables have a greater influence on grape and olive production than that on fig. The canonical correspondence analysis leads to the identification of two types of plots: Nablus, Jenin, Jericho and Gaza, whose production depends on the temperature and compensated thermicity index, which is the result of temperature nearly $20^{\circ} \mathrm{C}$, and a high compensated thermicity index. These conditions favor the production of olive and fig but not of grape, as these crops need values of annual ombrothermic index $<3$. Whereas, Hebron, Bethlehem, Jerusalem, Tulkarem and Ramallah are the plots whose production depends on the bioclimatic factors as ombrothermic index and continentally index, and climatic factors as precipitation, water deficit and soil water reserve.

Moreover, this study demonstrates for each crop the bioclimatic optimum, in which maximum production occurs, and in these situations, the use of water from the soil is not required for irrigation, also the highest production of grape is found in the south of Hebron, with olive production in the north and fig production in the central and other areas of Palestine.

\section{References}

[1] Kafle, H. and Bruins, H.J. (2009) Climatic Trends in Israel 1970-2002: Warmer and Increasing Aridity Inland. Climatic Change, 96, 63-77. http://dx.doi.org/10.1007/s10584-009-9578-2

[2] Alpert, P. and Reisin, T. (1986) An Early Winter Polar Air Mass Penetration to the Eastern Mediterranean. Monthly Weather Review, 114, 1411-1418.

[3] Alpert, P., Krichak, S.O., Shafir, H., Haim, D. and Osetinsky, I. (2008) Climatic Trends to Extremes Employing Regional Modeling and Statistical Interpretation over the E. Mediterranean. Global Planetary Change, 63, 163-170. http://dx.doi.org/10.1016/j.gloplacha.2008.03.003

[4] Alpert, P., Neeman, B.U. and Shay-El, Y. (1990) Climatological Analysis of Mediterranean Cyclones Using ECMWF Data. Tellus, 42A, 65-77. http://dx.doi.org/10.1034/j.1600-0870.1990.00007.x

[5] Samuels, R., Rimmer, A. and Alpert, P. (2009) Effect of Extreme Rainfall Events on the Water Resources of the Jordan River. Journal of Hydrology, 375, 513-523.

[6] Samuels, R., Rimmer, A., Hartmann, A., Krichak, S. and Alpert, P. (2010) Climate Change Impacts on Jordan River Flow: Downscaling Application from a Regional Climate Model. Journal of Hydrometeorology, 11, 860-879. http://dx.doi.org/10.1175/2010JHM1177.1

[7] Halfon, N., Levin, Z. and Alpert, P. (2000) Temporal Rainfall Fluctuations in Israel and Their Possible Link to Urban and Air Pollution Effects. Environmental Research Letters, 4, Article ID: 025001. http://dx.doi.org/10.1088/1748-9326/4/2/025001

[8] Ben-Gai, T., Bitan, A., Manes, S. and Alpert, P. (1994) Long-Term Changes in Annual Rainfall Patterns in Southern Israel. Theoretical and Applied Climatology, 49, 59-67. $\underline{\text { http://dx.doi.org/10.1007/BF00868190 }}$ 
[9] Bitan, A. and Saaroni, H. (1990) The Unusual Rain Spells of October 1985’. Israel Journal of Earth Sciences, 39, 33-46.

[10] Ighbareyeh, J.M.H., Cano-Ortiz, A. and Cano, E. (2014) Case Study: Analysis of the Physical Factors of Palestinian Bioclimate. American Journal of Climate Change, 3, 223-231. http://dx.doi.org/10.4236/ajcc.2014.32021.

[11] Cano, E. and Cano Ortiz, A. (2008) Olivicultura y medio ambiente. Instituto de Enseñanza Secundaria Jándula, Jaén, 95-123.

[12] Cano, E. and Cano Ortiz, A. (2008) Catástrofes y adaptaciones de las plantas. Instituto de Enseñanza Secundaria Jándula, Jaén, 125-136.

[13] Chloupek, O., Hrstkova, P. and Schweigert, P. (2004) Yield and Its Stability, Crop Diversity, Adaptability and Response to Climate Change, Weather and Fertilisation over 75 Years in the Czech Republic in Comparison to Some European Countries. Field Crops Research, 85, 167-190. http://dx.doi.org/10.1016/S0378-4290(03)00162-X

[14] De Blij, H.J. (1983) Geography of Viticulture: Rationale and Resource. Journal of Geography, 82, 112-121. http://dx.doi.org/10.1080/00221348308980792

[15] Rivas Martínez, S. (1996) Clasificación bioclimática de la Tierra. Folia Bot. Matritensis., 16, 1-20.

[16] Rivas Martínez, S. (2004) Worldwide Bioclimatic Classification System. www.globalbioclimatics.org

[17] Rivas-Martinez, S. (2008) Global Bioclimatic. http://www.globalbioclimatics.org

[18] Rivas-Martínez, S., Rivas-Sáenz, S. and Penas, A. (2011) Worldwide Bioclimatic Classification System. Global Geobotany, 1, 1-634.

[19] Jarque, C. and Bera, A. (1987) A Test for Normality of Observations and Regression Residuals. International Statistical Review, 55, 163-172. http://dx.doi.org/10.2307/1403192

[20] Jarque, C. and Bera, A. (1980) Efficient Tests for Normality Homoscedasticity and Serial Independence of Regression Residuals. Economics Letters, 6, 255-259. http://dx.doi.org/10.1016/0165-1765(80)90024-5

[21] Shapiro, S. and Wilk, M. (1965) An Analysis of Variance Test for Normality (Complete Samples). Biometrika, 52, 591-611. http://dx.doi.org/10.1093/biomet/52.3-4.591

[22] Shapiro, S., Wilk, M. and Chen, H. (1968) A Comparative Study of Various Tests for Normality. Journal of the American Statistical Association, 63, 1343-1372. http://dx.doi.org/10.1080/01621459.1968.10480932

[23] Ighbareyeh, J.M.H., Cano-Ortiz, A. and Cano, E. (2014) Biological and Bioclimatic Basis to Optimize Plant Production: Increased Economic Areas of Palestine. Agricultural Science Research Journal, 4, 10-20. http://www.resjournals.com/ARJ

[24] Galán, C., García-Mozo, H., Vázquez, L., Ruiz, L., Díaz de la Guardia, C. and Domínguez-Vilches, E. (2008) Modeling Olive CropYield in Andalusia, Spain. Agronomy Journal, 100, 98-104.

[25] Ighbareyeh, J.M.H., Cano-Ortiz, A., Suliemieh, A.A.A., Ighbareyeh, M.M.H. and Cano, E. (2014) Phytosociology with Other Characteristic Biologically and Ecologically of Plant in Palestine. American Journal of Plant Sciences, 5, 31043118. http://dx.doi.org/10.4236/ajps.2014.520327

[26] Alley, R.B., Marotzke, J., Nordhaus, W.D., Overpeck, J.T., Peteet, D.M., et al. (2003) Abrupt Climate Change. Science, 299, 2005-2010. http://dx.doi.org/10.1126/science.1081056

[27] IPCC (Intergovernmental Panel Climate Change) (2001) Climate Change 2001: The Science of Climate Change. Contribution of Working Group I to the Intergovernmental Panel on Climate Change Third Assessment Report. In: Houghton, J.T., Ding, Y., Griggs, D.J., Noguer, M., van der Linden, P.J., Dai, X., Maskell, K. and Johnson, C.A., Eds., Cambridge University Press, Cambridge.

[28] Karl, T.R. and Trenberth, K.E. (2003) Modern Global Climate Change. Science, 302, 1719-1723. http://dx.doi.org/10.1126/science.1090228

[29] Meehl, G.A., Zwiers, F., Evans, J., Knutson, T., Mearns, L. and Whetton, P. (2000) Trends in Extreme Weather and Climate Events: Issues Related to Modeling Extremes in Projections of Future Climate Change. Bulletin of the American Meteorological Society, 81, 427-436. http://dx.doi.org/10.1175/1520-0477(2000)081<0427:TIEWAC>2.3.CO;2

[30] Cano, E., Ruiz, L., García Fuentes, A., Melendo, M., Pinto Gomes, C.P., Torres, J.A., Salazar, C. and Valle, F. (1997) Phytonociologia apliqué a la planificación agrícola. Colloques Phytosociologiques, 27, 1007-1022.

[31] Cano, E., Ruiz, L., Melendo, M., Nieto, J. and Cano Ortiz, A. (2004) Bases bioclimáticas para laplanificación del olivar en el centro-sur de la Península Ibérica (España, Portugal). I conferencia mundial de IFOAN, Sobre el olivar ecológico: Producciones y culturas, Jaén, 305-311.

[32] Fraga, H., Malheiro, A.C., Moutinho-Pereira, J. and Santos, J.A. (2014) Climate Factors Driving Wine Production in the Portuguese Minho Region. Agricultural and Forest Meteorology, 185, 26-36. 
http://dx.doi.org/10.1016/j.agrformet.2013.11.003

[33] Grzeskowiak, L., Costantini, L., Lorenzi, S. and Grando, M.S. (2013) Candidate Loci for Phenology and Fruitfulness Contributing to the Phenotypic Variability Observed in Grapevine. Theoretical and Applied Genetics, 126, 2763-2776. http://rd.springer.com/article/10.1007/s00122-013-2170-1 http://dx.doi.org/10.1007/s00122-013-2170-1

[34] Winkler, A.J., Cook, J.A., et al. (1974) General Viticulture. 4th Edition, University of California Press, Berkley, 740 p.

[35] Coombe, B.G. (1987) Influence of Temperature on Composition and Quality of Grapes. Acta Horticulturae, 206, 2335.

[36] De Blij, H.J. (1985) Wine Quality and Climate. Focus, 35, 10-15.

[37] Mimi, Z., Ziara, M. and Nigim, H. (2003) Water Conservation and Its Perception in Palestine: A Case Study. Water and Environment Journal, 17, 152-156. http://dx.doi.org/10.1111/j.1747-6593.2003.tb00453.x

[38] Mizyed, N. (2009) Impacts of Climate Change on Water Resources Availability and Agricultural Water Demand in the West Bank. Water Resources Management, 23, 2015-2029. http://dx.doi.org/10.1007/s11269-008-9367-0

[39] Steinberger, E.H. and Gazit-Yaari, N. (1996) Recent Changes in the Spatial Distribution of Annual Precipitation in Israel. Journal of Climate, 9, 3328-3336. http://dx.doi.org/10.1175/1520-0442(1996)009<3328:RCITSD>2.0.CO;2

[40] Yair, A. and Kossovsky, A. (2002) Climate and Surface Properties: Hydrological Response of Small Arid and Semi-Arid Watersheds. Geomorphology, 42, 43-57.

[41] Yair, A. (1994) The Ambiguous Impact of Climate Change at a Desert Fringe: Northern Negev, Israel. In: Millington, A.C. and Pye, K., Eds., Environmental Changes in Drylands: Biogeographical and Geomorphological Perspectives, Wiley, New York, 199-227. 